\title{
Cultured meat: Do Chinese consumers have an appetite?
}

Chloe Dempsey \& Chris Bryant

Cellular Agriculture Society

July 2020

\section{Executive Summary}

This study examined the potential future for cultured meat in China, with a focus on the Chinese consumer. The study combined interviews with 17 stakeholders in this future (including incumbent industry, investors, start-ups and third sector representatives), with a survey of Chinese respondents $(n=1,020)$, which examined how different descriptions of cultured meat affected levels of acceptance, as well as preferred product format and key objections.

The results of the survey indicate that $70 \%$ of Chinese consumers are willing to try cultured meat, and $58 \%$ are already willing to buy it. We also find that Chinese consumers react more positively to descriptive framing of cultured meat that focus on food safety and health benefits, and in many instances are significantly less accepting of cultured meat when it is described as purely an imported product, or a scientific technology. These findings, and those of the study more broadly, are important because they indicate that advocates for cultured meat should make an effort to tailor their messaging to Chinese consumers. Considering that Chinese media is increasingly covering the subject of cultured meat, stakeholders should be proactive in shaping transparent narratives that focus on the intrinsic value of cultured meat to consumers.

The survey also identifies processed meat products as the most commonly preferred product Chinese consumers would purchase cultured meat as, suggesting that greater understanding of the Chinese processed meat market may be useful to the cultured meat industry. This should be supplemented by an understanding of the use of meat in Chinese cooking and how cultured meat products may be used in this context. 


\section{Background}

\subsection{Cultured meat}

The production of cultured meat is a recently developed method of growing animal meat for consumption that intends to avoid the environmental, health and welfare issues of industrially farmed animal meat (Post, 2012). It is not subject to the same vagaries of farming animals such as weather changes, animal disease, and volatility in commodity markets and global supply chains (Zhou \& Dieter, 2019).

Cultured meat is produced not through the slaughter of an animal, but through a growth process which originates with animal cells and is then undertaken in a separate environment outside of the animal. The process of cultivating meat may differ based on the application of technology and growth processes. Various types of meat have been cultured successfully, such as beef, pork, shrimp and fish (Kevany, 2019).

Research and development are continuing to improve the quality of cultured meat, including taste, nutritional profile and other areas relevant to the consumer experience (Choudhury, Tseng, \& Swartz, 2020). The high costs of production, the challenges of operating at scale, ensuring an ethical process, and creating complex cuts of meat (e.g. a T-bone steak), all remain ongoing issues for industry (Zhang, et al. 2020).

\subsection{China's growing demand for protein, and how cultured meat can contribute}

By 2025, China's protein market will be valued at over USD $\$ 113$ billion, more than triple the size of the second largest market, Europe, valued at USD\$35.9 billion (Food Innovation Australia Limited 2019). China's rapid economic development is driving a demand for meat that will be hard to satisfy, especially as various domestic and international restraints on supply are aggravated, including by disruptions to the global supply chain like COVID-19. In addition, China's struggle with the environmental and health repercussions of industrial animal agriculture are intensifying (Yu \& Wu, 2018).

China's current demand for meat is met by a mixture of domestic supply and international imports, both of which are currently threatened. African Swine Fever has decimated domestic populations of pigs, China's most commonly farmed animal, of which it produces over half of the world's global output (Huang, 2020). With over $40 \%$ of China's pig population dead or culled due to the disease in 2019, pork prices rose astronomically in the lead-up to Chinese New Year celebrations 2020, an issue considered to be of broad political importance (Hancock, 2019). 
There is also a limit on the long-term ability of Chinese agriculture to expand domestically; agrarian land is limited, as are water sources. While home to 20 percent of the world's population, China is home to only 7 percent of the world's arable land (Rossi 2018) and water (Shemie \& Vigerstol, 2016).

Limits on domestic supply have driven international imports of meat to China from all over the world, with South America and Australia as main sources (Hejazi et al., 2017). Supplies from these markets depend on volatile factors like the vicissitudes of animal populations broadly and threats to the supply chain posed by international and domestic crises. China's meat imports are also interwoven with its international diplomatic efforts, including the Belt and Road Initiative and controversial land acquisitions in Africa and Australia, which are also prone to unpredictability (Oliveira, 2017).

Given meat's status as a historical marker for the prosperity of society in China, the availability and cost of meat is of central importance to the everyday man, and hence to his government (Schneider \& Sharma, 2014). The speed and intensity with which senior Chinese Communist Party officials endeavoured to deal with the pork shortage in 2019/2020 makes it clear that meat supply is central to the ongoing development of China and the survival of its government (Hancock, 2019).

In short, the stability of China's supply of animal meat in a period of extraordinary growth in demand is far from guaranteed. Beyond pure cost and supply considerations, China also suffers considerably from the worst negative externalities of industrial agriculture of an environmental, health and ethical nature.

The Chinese government's first census on pollution stated that agriculture creates more water pollution than factories (Watt, 2010). Environmentally, industrial agriculture in China also worsens soil health and air pollution (Ellis, 2007). A recent study explored the potential for cultured meat in China from an environmental perspective and found that, environmentally, the replacement of conventionally farmed meat for cultured meat in China would require only $1.1 \%$ of the land that is currently used for meat production, and would lower greenhouse gas emissions from meat production by $85 \%$ (Sun, Yu and Han, 2015).

The health effects of industrially farmed meat have caused numerous scandals amongst Chinese consumers. This has included frequent incidences of 'fake', 'zombie' or 'synthetic' meat, incidences in which sold meat was found to have been decades-old and frozen (CNBC, 2015), or found to be meat from several species 'glued' together (Kaiman, 2013). Antimicrobial resistance associated with China's animal farming industry is frequently flagged as cause for concern not only domestically in China, but more globally too (Review on Antimicrobial Resistance, 2015). 
China's large, highly urbanised and dense population makes it more vulnerable to contagious zoonoses such as avian flu, from which it has already suffered multiple scares (Quan, Cao \& Zhu, 2014). $60-70 \%$ of emerging contagious diseases are zoonotic diseases including globally relevant examples such as COVID-19. While COVID-19 was traced to a wild animal wet market, factory farms are also breeding grounds for such zoonoses (Samuel, 2020).

Chinese farm animals have little legal protection in comparison to animals in other countries, with mistreatment, poor living standards and inhumane slaughter conditions commonplace (Sinclair, Zhang, Descovich, \& Phillips, 2020). The current mixed state of development of Chinese agriculture between small- and large-scale operations means that animal welfare is hard to police (Daly and Birtles 2019). Increases in industrialisation will allow for better policing, but will also guarantee animals a life of pain and suffering in the name of efficient production. Although many Chinese consumers are used to wet markets and the process of animal slaughter, making them less squeamish than many Western counterparts, consciousness about animal welfare is growing in China, and is set to grow as Chinese incomes and the industrialisation of animal farming increases (Chow, 2018).

In addition to the ability of cultured meat to address major issues associated with increasing meat demand in China, the Chinese market has some unique characteristics that may make it an ideal market for cultured meat. While cultured meat struggles through bureaucratic and regulatory hurdles in the US and other locations, China's unique policy and regulatory environment has the potential to encourage large-scale adoption and moves to market, on the proviso of Chinese government support. Stable, clean, less resource-limited and less polluting; cultured meat could be the silver bullet for China.

\subsection{The cultured meat landscape in Asia}

There are currently no mainland China-based cultured meat start-ups. While there has been initial research into cultured meat at some mainland Chinese universities (陈碧云 2019), this has been limited and has not yet been commercialized. A local industry group, the China Plant Based Foods Alliance, has held fora on the topic of cultured meat and claims to seek to advance the space in China (China Plant Based Foods Association, 2019). The Good Food Institute, a USbased think tank advocating for alternative proteins globally with some representation in China (as well as Brazil, Israel, Europe and Singapore), has focused its public work on plant-based protein (Siu and Miao 2019). In 2017, it was reported that the Chinese government invested in clean technology companies in Israel; while it was reported in some outlets that this included 
cultured meat, this has not been confirmed by companies or government sources (Israeli Ministry of Finance, 2017).

However, in the Asian region more broadly, there are a number of start-ups in early stages, including Avant Meats, based out of Hong Kong; Shiok Meats, based out of Singapore; and Vow Meats, based out of Australia, which were all interviewed for this study. Each of these sees itself as providing for an Asian consumer, and their products focus not on 'Western' meat products like beef steak, but instead on other varieties of meat and meat products such as fish maw, shrimp mince and kangaroo meat, respectively. Qualitative interviews with the founders of each of these companies indicate that they believe the Chinese consumer, market and barriers to entry are different to those in Western countries.

\subsection{Consumer acceptance of cultured meat in China and the West}

Despite the various economic and policy arguments that can be made in support of China as a cultured meat market, it is Chinese consumers who will determine whether this will actualize (or not). There is an absence of academic research I to provide sufficient insight into this critical question.

Research into consumer perceptions of cultured meat has been undertaken by academics, think tanks and polling groups in a number of locations globally. Research has not only focused on consumers' likelihood to try cultured meat (Hocquette, et al. 2015), but more specific studies have also explored which types of nomenclature (Bryant and Barnett 2019), narrative and consumer engagement may encourage a more positive reception, as well as what the major objections consumers tend to have are (Bryant and Barnett 2018).

The biggest predictor of opposition to cultured meat across a diverse range of factors (including distrust in science, naturalness bias, political conservatism and other commonly identified factors) has been shown to be food neophobia (Wilks, Phillips, Fielding \& Hornsey, 2019). Commonly found objections to cultured meat tend to centre around concerns about naturalness and disgust (Siegrist, Sütterlin and Hartmann 2018), although it is unclear whether respondents are reacting to naturalness per se or rationalizing post-judgment (Wilks et al. 2019). There are significant limitations to such research given the fact that cultured meat is not publicly available; the number of in-person experiments where participants are told they are consuming cultured meat is limited (Rolland, Markus, \& Post, 2020). Alongside academic research in the area, there has also been consumer polling and research done by think tanks cum industry lobbies; the Good Food Institute, New Harvest, and the Cellular Agriculture Society, among others (Cellular Agriculture Society 2019). 
Apart from some rare exceptions, all of this research has been undertaken in a Western context, from the United States, to the United Kingdom, to the EU (Bryant and Barnett 2018). Little to no consumer research has been undertaken in countries with an Asian, or non-Eurocentric majority population.

It has been determined that acceptance of new food technologies can be highly divergent based on cultural cognition and worldview, which makes clear the importance of undertaking consumer research among culturally diverse populations (Lusk, Roosen and Bieberstein 2014). While some beliefs and attitudes about cultured meat may be almost universal, without actually undertaking the same research with different populations, none of this can be assumed (Michaut 2004). Consequently, while there is a strong body of research on consumer attitudes towards cultured meat, this knowledge may not actually be applicable in a Chinese context.

An example of this is a recent study which explored whether nutritional enhancements to cultured meat can make consumers more accepting of the technology (Baumann and Bryant 2019). Participants were randomly assigned to read about either (a) cultured meat which was nutritionally identical to conventional meat, or (b) cultured meat which was nutritionally enhanced compared to conventional meat, including the addition of omega 3 . After reading the experimentally-manipulated passages, participants answered questions about cultured meat. While the study found significant differences between the groups, these were only in regards to respondents' beliefs about the healthiness of the product and its benefit for society, and did not correspond to any significant differences in behavioural intentions; respondents' willingness to try, buy, pay more or substitute cultured meat for conventional meat. This was the finding with a US sample, but Chinese attitudes may be completely different given the alternate view of nutrition in China, influenced by holistic perspectives on food, traditional Chinese medicine and philosophy. In a recent survey of Chinese consumers, $77 \%$ of respondents said that in making healthy food choices, nutritional content is more important to me than flavour' (Phelps 2018). Beliefs about when certain types of food should be eaten, and what specific effect they can have on health, are commonplace in China, including in reference to meat (South China Morning Post, n.d.). This is one example of different sets of attitudes and beliefs between cultures, and this is likely to have an impact on the behavioural intentions of consumers in regards to cultured meat.

Research has made clear that the way cultured meat is described influences its perception and acceptance among consumers (Siegrist, Sütterlin and Hartmann 2018). Some of the most generally applicable consumer research done in this area examines the effects that narrative framing can have on acceptance levels (Bryant and Dillard 2019). In their study, Bryant and Dillard presented respondents with a survey that used one of three alternating experimental conditions. 
Each of the three experimental conditions presented a different frame i.e. a description framing cultured meat as: being a scientific technology, a boon for the environment and animals, and having the same taste as conventional meat. The research found that the frame through which cultured meat was presented significantly affected respondent's acceptance levels. The frame which most accurately reflected the current media depiction of cultured meat, i.e. as high-tech, was the most negatively received. This may be unsurprising considering that laboratories are, by nature, unnatural places, which runs contrary to our traditional association of meat with animals and nature. This research is important because it demonstrates that, if industry or advocates are able to help contribute to the public narrative created by media surrounding cultured meat, they may be able to also change consumer acceptance levels.

Other research conducted on the topic explored consumer acceptance levels dependent on exposure to different names for cultured meat (Bryant and Barnett 2019). Different names significantly affected attitudes, beliefs and behavioural intentions of respondents towards cultured meat. This study concluded by noting the importance of exploring names in different linguistic contexts given the complex connotations of words and concepts across cultures, languages and borders.

Minimal research has been undertaken on Chinese perceptions of cultured meat. So far, only one academic survey has examined Chinese consumer acceptance levels of cultured meat, in the context of comparative research with other countries and products. This research compared attitudes in the US, India and China on cultured and plant-based meat (Bryant, Szejda, et al. 2019). There are also two further known data sources on Chinese consumer responses to cultured meat, although neither have been published academically and their methodology cannot be examined. The first was undertaken by a public opinion company and compared attitudes towards cultured meat in countries across Asia (YouGov 2018). The second was undertaken by an affiliated think tank of the New Zealand government and explored protein in China with one question on cultured meat (Phelps 2018). The aforementioned research was undertaken in the context of broader studies and the researchers were not Chinese or resident in China.

The results of these three pieces of research were inconclusive on Chinese consumer acceptance levels. The YouGov survey claimed that only $26 \%$ of Chinese consumers 'would probably try' cultured meat; while the NZ survey found that over $52 \%$ of respondents were 'probably or very likely' to purchase cultured meat; and the US-India-China survey found that over $93 \%$ of respondents were 'somewhat to extremely likely' to purchase cultured meat.

The difference in the survey instruments used by each study cannot be ascertained in the case of the YouGov and NZ surveys. The survey by Bryant et al measured responses to a series of 
behavioral intention statements using a 5-point Likert scale which was not evenly balanced as only one option reflected disagreement while the four others favored agreement (i.e. not at all likely, somewhat likely, moderately likely, very likely, extremely likely). This imbalanced scale may open the research up to response bias (Malhotra 2006).

This is compounded by research which indicates that Asian survey respondents are more likely to avoid extreme response styles in surveys (Peterson, Rhi-Perez and Albaum 2014), more commonly placing in the middle of Likert-style scales, which in this instance would have produced biased results in favour of higher rates of cultured meat acceptance.

Additionally, the name used for cultured meat in that survey was one that may have biased responses as it was not neutral (纯净肉, chunjingrou, literally: purity meat). It has been demonstrated that names can have a significant impact on acceptance levels of cultured meat (Bryant and Barnett 2019) and previous use of the term 'clean meat' in an English language context has been largely moved away from because of its perceived bias (Choi, 2018).

The authors also noted limitations of the survey, mostly based on the fact that the demographic background of respondents was skewed, with most of them being middle income, highly-educated urbanites. While the YouGov and NZ survey did not give demographic information about their respondents, it would be useful to attempt to replicate these surveys with a more diverse demographic to understand which finding is accurate.

Considering the above, there is not yet any clear indication of consumer attitudes towards cultured meat in China. Aside from the aforementioned research, no further known research has been undertaken, leaving many gaps in knowledge on what may be the best way for industry stakeholders to proceed should the Chinese market for cultured meat open.

In attempting to fill some of these gaps, this study adopted some of the same methodology and focus of previous research into consumer attitudes towards cultured meat in Western contexts, adapting these to the Chinese population. Additionally, the research seeks to clarify the findings of prior research, by broadening the demographics of the respondent pool, and by using a more balanced survey tool. 


\section{Methodology}

\subsection{Interviews}

17 interviews were undertaken with selected stakeholders in order to understand the potential response of Chinese consumers to cultured meat, as well as more broadly on the potential for such an industry to develop domestically or enter China. Stakeholders were staff or founders at cultured meat companies (Memphis Meats, Avant Meats, Shiok Meats, Vow Food), non-profit staff working in related areas (Good Food Institute, China Plant Based Foods Association, independent researchers), people with local or policy expertise in China (China Policy, Austrade, Nanjing Audit University), investors (Dao Foods, Lever VC, Bits X Bites) and incumbent companies (New Hope Group, COFCO, unnamed company). These interviews were semistructured and of a duration of 30-60 minutes each. Interviews were undertaken either in person or over the phone.

A mixed structure was used, in which the interviewer led with a series of questions shared across all interviews, followed by specific questions based on the interviewee's own background, before finally the interviewee was given the chance to highlight areas of importance to them that the researcher may not be aware of. The generic questions discussed the future of cultured meat in China, its barriers and potential, how Chinese consumers may react to it, as well as what major gaps in knowledge existed in the widely available literature and public forum. This feedback also helped inform the development of the survey instrument.

\section{2 Survey design}

The survey had three aims. The first was to conduct original research with Chinese consumers to clarify prior findings on Chinese consumer acceptance levels. The second was to explore topics not yet broached by the existing literature but highlighted by industry through the qualitative interviews as relevant and important. The third was to investigate the impact of different messages on cultured meat acceptance. The first two aims were addressed by adding certain features to the survey and using cross-sectional data, however the third aim necessitated the use of an experimental design.

Quantitative data was gathered through an online experimental survey instrument, where respondents were randomly allocated to one of five groups with differently framed descriptions of cultured meat, modelled on a similar survey on the effects of framing undertaken in the US (Bryant \& Dillard, 2019). 
Aside from questions intending to gauge consumer responses dependent on frame, the survey asked questions more specific to the form of product that may be preferred by Chinese consumers, including which names were considered most attractive and appropriate for cultured meat. Respondents also gave qualitative responses about their objections to cultured meat, through an open question, prompted for respondents who consistently responded negatively to questions gauging acceptance of cultured meat. Demographic data was also collected. Respondents were paid a minimum of three yuan to complete the survey.

In order to ensure compliance with ethical research standards, respondents gave consent before taking part in the survey. Participants were also screened using a logic test a third of the way into the survey. If respondents failed to answer the logic test correctly their responses were not included in the final results.

The survey commenced with randomly allocating respondents to one of five experimental conditions each with a different descriptive frame. There are obvious issues with the reliability of data that is self-reported, especially in an environment that respondents feel is artificial and manufactured. For this reason, the introductory descriptions were designed with consideration of ecological validity and were presented as legitimate news articles published by the People's Daily (renmin ribao, 人民日报); a state news broadcaster that publishes extensively across various media platforms in China, and is the largest newspaper group in China. We note the use of a similar technique representing mock news articles in previous research on the topic (The Good Food Institute, 2017). While this media source may not be considered particularly academic, the descriptive frames were short and succinct, using language that is easily comprehensible and clear. Respondents were informed at the conclusion of the survey that these articles were falsified. Pictures of the articles can be found in the Appendix. Translated versions of the text can be found on the page following in Table 1.

Two of the frames were modelled off those used in the original experimental survey by Bryant and Dillard (2019), while three new frames were designed after consultation with Chinese food industry experts (as part of the interviews), in line with consumer trends in food. A control group was not used. As per the rationale of the authors of the original study, this is due to the fact that in reality no control group may exist: any introduction of cultured meat will necessarily present information and hence have a framing effect.

While many aspects of the experimental survey undertaken in the US by Bryant and Dillard were imitated, one aspect was deliberately abandoned, which was the multimodal nature of frames that were used for that survey. This is because images are known to significantly affect responses, and combining an image with text and then measuring the effectiveness of the frame will make it hard to ascertain whether this response was elicited by the image or the text. In reality, 
when industry has an opportunity to engage with consumers, through news media or other coverage, the content over which they have control is often a quote or articulated opinion, rather than an image.

\section{Table 1: Experimental Conditions/Frames}

$1 \quad$ Cultured meat: a new scientific achievement

Cultured meat, also called cell-based meat, is meat which is grown from animal cells without the need to raise animals. It is real meat, and has the same taste and texture as conventional meat. The meat is grown using highly advanced technology in a stateof-the-art laboratory. The meat is grown from cells placed in a bioreactor and fed a nutrient media. Cultured meat could be available to consumers in China within 3 years.

2 Cultured meat: a way to save animals and the planet

Cultured meat, also called cell-based meat, is meat which is grown from animal cells without the need to raise animals. It is real meat, and has the same taste and texture as conventional meat. In contrast to conventional meat, cultured meat does not require animals to suffer and be slaughtered. Also, cultured meat has a far lower environmental footprint; using less water and resources, and producing fewer greenhouse gas emissions compared to conventional meat. Cultured meat could be available to consumers in China within 3 years.

3 Cultured meat: a healthier meat

Cultured meat, also called cell-based meat, is meat which is grown from animal cells without the need to raise farm animals. It is real meat, and has the same taste and texture as conventional meat. In comparison to conventional meat, cultured meat has less fat. Compared to conventional meat, vitamins and minerals can also be added to give additional health benefits compared to conventional meat. Cultured meat doesn't include salmonella or other germs, so it can help to reduce the probability of zoonoses. Cultured meat could be available to consumers in China within 3 years.

$4 \quad$ Cultured meat: popular overseas

Cultured meat, also called cell-based meat, is meat which is grown from animal cells without the need to raise farm animals. It is real meat, and has the same taste and texture as conventional meat. In the United States, Europe, Australia and Asia multiple cultured meat companies already exist. Singapore and the United States are close to approving the sale of cultured meat to the general public. Cultured meat could be available to consumers in China within 3 years.

$5 \quad$ Cultured meat: improving Chinese food security

Cultured meat, also called cell-based meat is meat which is grown from animal cells without the need to raise farm animals. It is real meat, and has the same taste and texture as conventional meat. Unlike conventional meat, cultured meat will not be affected by animal diseases such as swine fever. It is also not dependent on changing conditions like the availability of farmland or water, ensuring a stable supply and price. Cultured meat could be available to consumers in China within 3 years. 
The two frames replicated from the original study were originally crafted based on both their existence in dominant media discourse on cultured meat and also their diverging connotations and associations (Bryant and Dillard 2019). The first focused on the high-tech aspect of cultured meat and referred to its production, raising ideas commonly associated with nomenclature like 'lab-grown meat', 'artificial meat' and 'synthetic meat'. This was replicated because, similar to the reasoning of the original researchers, the dominant narrative of cultured meat that has been presented in the Chinese media also relates to the scientific and technological aspect of the product, and is often contextualised by a focus on the laboratory.

The second emphasised the environmental and animal welfare (broadly, ethical) benefits of cultured meat. In replicating this frame, a highlight is placed on the ongoing debate as to whether Chinese consumers are interested in making consumption choices based on ethical impact given that environmental and animal rights movements are slowly gathering traction domestically, but do not have the same history and development as in Western countries. It has been hypothesised that for the majority of Chinese who may have grown up going to wet markets and seeing the slaughter of animals, they are less squeamish about the violent reality of slaughter (Tian, Hilton, \& Becker, 2018). The third frame from Bryant and Dillard's survey, which emphasized the similarity of cultured meat to conventional meat, was not repeated, in order to allow for other, new frames to be introduced.

The third frame focused on the health and food safety benefits of cultured meat. It noted that the nutritional profile of cultured meat could be enhanced, and is absent of animal-borne bacteria such as salmonella and zoonotic diseases. Ongoing food safety concerns in China remain one of the key focuses of the government and the broader population. Chinese culture tends to consider food as a holistic part of health and wellbeing, with various types of food considered to have different properties and applications. Preoccupations with the nutritional profile of products, especially for consumption by children and the elderly, important demographic groups due to an aging population and the one child policy, are commonplace (Browning, Qiu, Yang, Zhang, \& Thomas, 2019). This frame also allowed for a comparison with recent research done demonstrating that for US consumers, an enhanced nutritional profile did not encourage greater acceptance of cultured meat (Baumann and Bryant 2019).

The fourth frame focussed on the purported acceptance of cultured meat overseas. It noted that a number of companies in the US and Europe were working on this technology and would soon finish regulating the area and begin selling cultured meat products. This sought to use momentum from another trend related to food safety: trust in overseas food products. Food regulation and safety regimes in other countries have been historically stronger than domestically 
in China, raising demand for certain imported items favoured over their domestic equivalents (Kendall et al., 2018). This ranges from the classic example of milk powder (following the melamine scandal in 2008, see BBC, 2010), all the way to meat itself. Additionally, as Chinese incomes grow, aspirational lifestyle trends increase, which are sometimes modelled on wellestablished trends in Western countries. This frame also reflects prior research that concluded consumers are more positive about cultured meat when they are told it has a larger market share (Slade, 2018).

The fifth frame described cultured meat as a reliable and price-stable supply source of protein in comparison to conventional meat. The frame stated that cultured meat did not have the same dependence on volatile natural resources and weather conditions, and that it would not be subject to the same dangers affecting animal populations, like swine fever. This frame aligned with a very topical issue in the form of African swine fever, well known to have ploughed down pig headcounts across China, causing the price of pork to skyrocket during the annual high season of lunar new year 2020 (Reuters, 2020).

Following exposure to one of the frames, respondents were asked about whether they previously had heard of cultured meat. The debate surrounding the nomenclature on cultured meat is extensive. While cultured meat is currently the chosen term by the main industry lobbyists, other terms currently in use include cell-based meat, cultured meat, clean meat and others. This can complicate surveys where only one term is used and respondents are initially asked whether they know what the technology is: their response may reflect a lack of familiarity with the name, rather than the concept. Although the debate has not been as extensive in China, there is arguably even more confusion within the Mandarin language about what to call cultured meat. For this reason, the survey first described cultured meat before asking if respondents had previously heard of it. The survey also asked if people understood cultured meat, as well as whether they wanted to know more. This latter question provided a measure on general respondent interest in cultured meat, though it is possible that such a question elicits some positivity bias.

Respondents were then presented with four statements measuring consumer acceptance of cultured meat through behavioural intentions with an accompanying Likert scale (with 5 points from very willing to very unwilling). The phrasing of these questions were the same as those used in the original experimental survey by Bryant and Dillard, as well as in the US-India-China comparative survey, and measured consumers' self-reported willingness to try, buy and pay more for cultured meat, as well as substitute their use of conventional meat with cultured meat. These statements had a very high Cronbach's Alpha score $(>0.9)$, indicating that they had a strong correlation in measuring the same construct; namely how accepting and open respondents were 
to cultured meat. At the conclusion of the survey those respondents who answered all these behavioural intention statements negatively were given an option to expand on their opposition to cultured meat with an open-ended question.

Following this, respondents were presented with a series of statements reflecting attitudes and beliefs. 'Cultured meat is:' was followed by a list of adjectives such as 'healthy', 'safe', 'good for the environment', as well as some negative adjectives such as 'evil'. The same adjectives were listed after the statement, 'conventional meat is:'. This mirrored the survey design of the US-IndiaChina comparative study, as well as many other surveys in this area (Wilks and Phillips, 2017). In this way, respondents' attitudes towards cultured and conventional meat could be compared.

In the second part of the survey, respondents were asked about their own meat consumption habits, as well as what form they would be willing to purchase cultured meat in. These questions addressed important gaps in knowledge which were highlighted by industry stakeholders during qualitative interviews. This investigated the possibility that Chinese consumers may be more willing to try cultured meat in formats other than those being developed by the majority of companies in the area currently. The survey asked respondents whether they had consumed various formats of meat in their last three meals, and then whether they would be willing to buy those same formats of cultured meat. The list of formats was extensive and reflective of the diversity of meat consumption in China, including meat floss, dried meat and processed meat products.

The last of the substantive questions asked respondents which names they believed were most accurate, as well as most attractive, for cultured meat. A former informal study was undertaken by the authors of the US-India-China comparative survey to understand which Mandarin name for cultured meat was most attractive (for use in their survey). This was with a limited sample of 164 people, which indicated a preference for the name chunjingrou (literally: 'purity meat', 纯净肉).

Finally, respondents were asked demographic questions including their age, gender, dietary habits, education level, religion, birthplace, location and income. 


\section{Results}

\subsection{Survey: demographics}

Responses to the survey were collected through the online survey service, Wenjuanxing (问 卷星) in November 2019. 1,100 respondents engaged with the survey, 8 of whom did not consent to take part, and 72 of whom failed to pass the simple logic question inserted after the first third of the survey. This left a total of 1,020 completed responses. The demographics of respondents are represented in Table 2 on the page following. The sample was nationally representative in terms of age and gender, and represented a good range of locations, education levels, and income levels (although the final sample was slightly skewed towards younger and more educated people). This represented a more diverse group than previous surveys, importantly representing more people from a low-income background, and more people from a rural background.

\subsection{Survey: overall findings}

$70 \%$ of respondents were willing to try cultured meat, $58 \%$ were willing to buy it; and $34 \%$ were willing to substitute their use of conventional meat for cultured meat. Further, $16 \%$ were willing to pay more for cultured meat than for conventional meat. Those who did not have an opinion either way averaged about $30 \%$ for each statement, although in regards to trying cultured meat, only $8 \%$ of respondents were not willing, transferring to $13 \%$ not willing to buy cultured meat, $25 \%$ not willing to substitute and $54 \%$ not willing to pay more.

When attitudinal statements about cultured meat were contrasted against conventional meat, $91 \%$ of respondents believed that cultured meat was more or as good to animals as conventional meat, $86 \%$ believed that it was more or as environmental as conventional meat, $81 \%$ believed it was more or as good for society, $79 \%$ believed it was more or as reliable a source of protein, and $72 \%$ believed it was more or as costly to purchase as conventional meat. Further, $71 \%$ of respondents rated cultured meat at least as safe as conventional meat, while $75 \%$ considered it at least as healthy and $59 \%$ considered it just as nutritious. Conversely, just $47 \%$ of respondents believed that cultured meat was as natural as conventional meat. 
Table 2: Demographics of Respondents

\begin{tabular}{|c|c|c|c|c|c|}
\hline Gender & $\#$ & $\%$ & Age & $\#$ & $\%$ \\
\hline Male & 532 & 52.2 & $<24$ & 344 & 33.7 \\
\hline Female & 487 & 47.7 & $25-39$ & 418 & 41 \\
\hline Prefer not say & 1 & 0.1 & $40-55$ & 258 & 25.3 \\
\hline Birth location & \# & $\%$ & Education & & $\%$ \\
\hline Urban & 476 & 46.7 & High school & 199 & 19.5 \\
\hline Rural & 544 & 53.3 & Vocational & 73 & 7.2 \\
\hline Residence location & & $\%$ & Undergraduate & 675 & 66.2 \\
\hline Urban & 86.7 & 884 & Masters & 68 & 6.7 \\
\hline Rural & 13.3 & 136 & PhD & 5 & .5 \\
\hline Income (mo.) & $\#$ & $\%$ & Religion & \# & $\%$ \\
\hline$<3,000$ & 414 & 40.6 & Prefer not say & 63 & 6.2 \\
\hline $3-6,000$ & 183 & 17.9 & Atheist & 819 & 80.3 \\
\hline $6-10,000$ & 246 & 24.1 & Christian & 23 & 2.3 \\
\hline $10-20,000$ & 143 & 14 & Daoist & 10 & 1 \\
\hline$>20,000$ & 34 & 3.3 & Buddhist & 90 & 8.8 \\
\hline Diet & \# & $\%$ & Muslim & 3 & 0.3 \\
\hline Omnivore & 1,004 & 98.4 & Jewish & 1 & 0.1 \\
\hline Pescatarian & 13 & 1.3 & Confucian & 11 & 1.1 \\
\hline Vegetarian & 2 & 0.2 & & & \\
\hline Vegan & 1 & 0.1 & & & \\
\hline
\end{tabular}




\section{3 Survey: knowledge of cultured meat}

$40 \%$ of respondents stated that they had heard of cultured meat prior to the survey. When prior knowledge was measured as binary (yes or no), there were not many significant differences between those who had or did not have prior knowledge of cultured meat. Just two attitudinal measures showed a significant difference between these groups: those who had heard of cultured meat before rated it significantly less natural, but significantly better for animals. The lack of significant differences with respect to environmental and other benefits suggests these are not obvious to Chinese consumers even if they have heard of cultured meat.

After reading descriptions, only $54 \%$ of respondents said they knew what cultured meat was, but those respondents were significantly more likely to try, buy and substitute cultured meat in their diet. They were also significantly more likely to assess cultured meat as good for the environment, good for animals, good for society, reliable, and tasty. They also rated it as significantly less natural, indicating that perceived naturalness is not necessarily important for Chinese consumers.

$85 \%$ of respondents stated that they wanted to know more about cultured meat, and that group was significantly more likely to try, buy and substitute cultured meat over their use of conventional meat, as well as being generally more likely to pay more for cultured meat than conventional meat.

\subsection{Survey: experimental findings}

The data was analysed using the same tool as that used in the original survey by Bryant and Dillard; an omnibus one-way analysis of variance (ANOVA). Tukey's B tests were used for posthoc analyses. Analysis was undertaken using Statistical Package for Social Sciences (SPSS) Version 25. For those statements that were negative e.g. that cultured meat is evil, the scores received were reverse coded, to align with the majority of scoring, in which a higher score indicated a more positive response.

Table 3 and 4 on the pages following show the means and standard deviations as well as the outcomes of the ANOVAs, including the relevant $p$ values. In the case of all behavioral intention statements except willingness to try (which had universally high responses; only $8 \%$ would not be willing to try), there was a statistically significant difference between sample groups based on the experimental condition they were exposed to. 
Table 3: Attitudes Cultured Meat in China

\begin{tabular}{|c|c|c|c|c|c|c|c|c|}
\hline \multirow[t]{2}{*}{ Variable } & \multirow{2}{*}{$\begin{array}{l}\text { Overall } \\
\text { mean }\end{array}$} & \multicolumn{5}{|c|}{ Condition mean (and Standard Deviation) } & \multicolumn{2}{|c|}{ ANOVA } \\
\hline & & $\begin{array}{l}\text { Ethical } \\
\text { impact }\end{array}$ & $\begin{array}{c}\text { Reliable } \\
\text { supply }\end{array}$ & $\begin{array}{l}\text { Health } \\
\text { benefits }\end{array}$ & $\begin{array}{l}\text { High - } \\
\text { tech }\end{array}$ & $\begin{array}{l}\text { Accepted } \\
\text { overseas }\end{array}$ & $\mathrm{F}$ & p \\
\hline Good for the environment* & $\begin{array}{c}4.12 \\
(0.938)\end{array}$ & $\begin{array}{c}4.46 \\
(0.869)\end{array}$ & $\begin{array}{c}4.07^{\mathrm{a}} \\
(0.912)\end{array}$ & $\begin{array}{c}3.99^{\mathrm{a}} \\
(0.947)\end{array}$ & $\begin{array}{c}4.05^{\mathrm{a}} \\
(0.961)\end{array}$ & $\begin{array}{c}4.01^{\mathrm{a}} \\
(0.925)\end{array}$ & 9.17 & $<0.001$ \\
\hline Safe* & $\begin{array}{c}3.44 \\
(1.033)\end{array}$ & $\begin{array}{c}3.35^{\mathrm{ac}} \\
(0.970)\end{array}$ & $\begin{array}{c}3.61^{\mathrm{bc}} \\
(1.036)\end{array}$ & $\begin{array}{c}3.73^{\mathrm{b}} \\
(1.010)\end{array}$ & $\begin{array}{c}3.31^{\mathrm{a}} \\
(1.029)\end{array}$ & $\begin{array}{c}3.21^{a} \\
(1.034)\end{array}$ & 9.51 & $<0.001$ \\
\hline Evil* $^{*}$ & $\begin{array}{c}3.91 \\
(0.868)\end{array}$ & $\begin{array}{c}4.07^{\mathrm{bc}} \\
(0.820)\end{array}$ & $\begin{array}{c}3.96^{\mathrm{ac}} \\
(0.840)\end{array}$ & $\begin{array}{l}3.99^{\mathrm{abc}} \\
(0.813)\end{array}$ & $\begin{array}{c}3.78^{a} \\
(0.922)\end{array}$ & $\begin{array}{c}3.75^{a} \\
(0.900)\end{array}$ & 5.22 & $<0.001$ \\
\hline Good for society* & $\begin{array}{c}3.77 \\
(0.790)\end{array}$ & $\begin{array}{c}3.97^{\mathrm{bc}} \\
(0.760)\end{array}$ & $\begin{array}{c}3.84^{\mathrm{ac}} \\
(0.738)\end{array}$ & $\begin{array}{c}3.79^{\mathrm{ab}} \\
(0.702)\end{array}$ & $\begin{array}{c}3.68^{a} \\
(0.846)\end{array}$ & $\begin{array}{c}3.61^{a} \\
(0.852)\end{array}$ & 6.53 & $<0.001$ \\
\hline Healthy* & $\begin{array}{c}3.61 \\
(0.855)\end{array}$ & $\begin{array}{c}3.65^{c} \\
(0.896)\end{array}$ & $\begin{array}{c}3.74^{\mathrm{bc}} \\
(0.806)\end{array}$ & $\begin{array}{c}3.88^{\mathrm{b}} \\
(0.786)\end{array}$ & $\begin{array}{c}3.39^{a} \\
(0.822)\end{array}$ & $\begin{array}{c}3.38^{a} \\
(0.855)\end{array}$ & 14.13 & $<0.001$ \\
\hline Cruel to animals* & $\begin{array}{c}4.06 \\
(0.879)\end{array}$ & $\begin{array}{c}4.35 \\
(0.809)\end{array}$ & $\begin{array}{c}3.98^{a} \\
(0.813)\end{array}$ & $\begin{array}{c}3.99^{a} \\
(0.980)\end{array}$ & $\begin{array}{c}4^{a} \\
(0.890)\end{array}$ & $\begin{array}{c}3.97^{a} \\
(0.838)\end{array}$ & 7.21 & $<0.001$ \\
\hline Nutritious* & $\begin{array}{c}3.53 \\
(0.892)\end{array}$ & $\begin{array}{c}3.52^{a} \\
(0.892)\end{array}$ & $\begin{array}{c}3.5^{a} \\
(0.830)\end{array}$ & $\begin{array}{c}3.79 \\
(0.859)\end{array}$ & $\begin{array}{c}3.4^{a} \\
(0.880)\end{array}$ & $\begin{array}{c}3.44^{\mathrm{a}} \\
(0.949)\end{array}$ & 6.11 & $<0.001$ \\
\hline Reliable* & $\begin{array}{c}3.9 \\
(0.984)\end{array}$ & $\begin{array}{c}3.8^{a} \\
(0.965)\end{array}$ & $\begin{array}{c}4.12^{\mathrm{b}} \\
(0.935)\end{array}$ & $\begin{array}{c}3.88^{a b} \\
(0.929)\end{array}$ & $\begin{array}{c}3.86^{a b} \\
(1.012)\end{array}$ & $\begin{array}{c}3.86^{\mathrm{ab}} \\
(1.049)\end{array}$ & 3.32 & 0.010 \\
\hline Natural & $\begin{array}{c}2.46 \\
(1.159)\end{array}$ & $\begin{array}{c}2.52 \\
(1.191)\end{array}$ & $\begin{array}{c}2.64 \\
(1.259)\end{array}$ & $\begin{array}{c}2.41 \\
(1.079)\end{array}$ & $\begin{array}{c}2.37 \\
(1.124)\end{array}$ & $\begin{array}{c}2.36 \\
(1.123)\end{array}$ & 2.11 & 0.078 \\
\hline Tasty & $\begin{array}{c}3.15 \\
(0.801)\end{array}$ & $\begin{array}{c}3.2 \\
(0.786)\end{array}$ & $\begin{array}{c}3.19 \\
(0.782)\end{array}$ & $\begin{array}{c}3.2 \\
(0.838)\end{array}$ & $\begin{array}{c}3.07 \\
(0.782)\end{array}$ & $\begin{array}{c}3.06 \\
(0.809)\end{array}$ & 1.64 & 0.163 \\
\hline Expensive & $\begin{array}{c}2.65 \\
(0.930)\end{array}$ & $\begin{array}{c}2.67 \\
(0.919)\end{array}$ & $\begin{array}{c}2.77 \\
(0.956)\end{array}$ & $\begin{array}{c}2.6 \\
(0.922)\end{array}$ & $\begin{array}{c}2.63 \\
(0.914)\end{array}$ & $\begin{array}{c}2.56 \\
(0.934)\end{array}$ & 1.62 & 0.168 \\
\hline Same as conventional meat & $\begin{array}{c}3.47 \\
(1.103)\end{array}$ & $\begin{array}{c}3.53 \\
(0.992)\end{array}$ & $\begin{array}{c}3.51 \\
(1.028)\end{array}$ & $\begin{array}{c}3.43 \\
(0.945)\end{array}$ & $\begin{array}{c}3.53 \\
(1.037)\end{array}$ & $\begin{array}{c}3.38 \\
(1.062)\end{array}$ & 0.89 & 0.473 \\
\hline
\end{tabular}


Table 4: Behavioural intentions

\begin{tabular}{|c|c|c|c|c|c|c|c|c|}
\hline \multirow[t]{2}{*}{ Variable } & \multirow{2}{*}{$\begin{array}{l}\text { Overall } \\
\text { mean }\end{array}$} & \multicolumn{5}{|c|}{ Condition Mean (and Standard Deviation) } & \multicolumn{2}{|c|}{ ANOVA } \\
\hline & & $\begin{array}{l}\text { Health } \\
\text { benefits }\end{array}$ & $\begin{array}{l}\text { Ethical } \\
\text { impact }\end{array}$ & $\begin{array}{l}\text { Reliable } \\
\text { supply }\end{array}$ & $\begin{array}{l}\text { High } \\
\text { tech }\end{array}$ & $\begin{array}{l}\text { Accepted } \\
\text { overseas }\end{array}$ & $\mathrm{F}$ & $\mathrm{p}$ \\
\hline $\begin{array}{l}\text { Willingness to } \\
\text { try }\end{array}$ & $\begin{array}{c}3.77 \\
(0.873)\end{array}$ & $\begin{array}{c}3.85 \\
(0.791)\end{array}$ & $\begin{array}{c}3.8 \\
(0.892)\end{array}$ & $\begin{array}{c}3.82 \\
(0.811)\end{array}$ & $\begin{array}{c}3.76 \\
(0.870)\end{array}$ & $\begin{array}{c}3.62 \\
(0.979)\end{array}$ & 2.17 & 0.07 \\
\hline $\begin{array}{l}\text { Willingness to } \\
\text { buy* }\end{array}$ & $\begin{array}{c}3.53 \\
(0.907)\end{array}$ & $\begin{array}{c}3.62^{\mathrm{a}} \\
(0.880)\end{array}$ & $\begin{array}{l}3.55^{\mathrm{ab}} \\
(0.863)\end{array}$ & $\begin{array}{c}3.65^{a} \\
(0.898)\end{array}$ & $\begin{array}{c}3.47^{\mathrm{ab}} \\
(0.875)\end{array}$ & $\begin{array}{c}3.35^{\mathrm{b}} \\
(0.990)\end{array}$ & 3.71 & 0.005 \\
\hline $\begin{array}{l}\text { Willingness to } \\
\text { substitute* }^{*}\end{array}$ & $\begin{array}{c}3.11 \\
(0.968)\end{array}$ & $\begin{array}{c}3.18^{\mathrm{ab}} \\
(0.971)\end{array}$ & $\begin{array}{c}3.27^{a} \\
(1.015)\end{array}$ & $\begin{array}{c}3.12^{\mathrm{ab}} \\
(0.867)\end{array}$ & $\begin{array}{c}3.04^{\mathrm{ab}} \\
(0.921)\end{array}$ & $\begin{array}{c}2.96^{\mathrm{b}} \\
(1.036)\end{array}$ & 3.24 & 0.012 \\
\hline $\begin{array}{l}\text { Willingness to } \\
\text { pay more* }\end{array}$ & $\begin{array}{c}2.52 \\
(0.968)\end{array}$ & $\begin{array}{c}2.72^{\mathrm{b}} \\
(0.938)\end{array}$ & $\begin{array}{l}2.62^{a b} \\
(0.990)\end{array}$ & $\begin{array}{c}2.55^{\mathrm{ab}} \\
(0.957)\end{array}$ & $\begin{array}{c}2.46^{a} \\
(0.949)\end{array}$ & $\begin{array}{c}2.23^{\mathrm{a}} \\
(0.944)\end{array}$ & 7.64 & 0.001 \\
\hline $\begin{array}{l}\text { Composite of } \\
\text { behavioral } \\
\text { intentions }\end{array}$ & $\begin{array}{c}12.92 \\
(3.062)\end{array}$ & $\begin{array}{l}13.38^{a} \\
(2.914)\end{array}$ & $\begin{array}{l}13.24^{a} \\
(3.117)\end{array}$ & $\begin{array}{l}13.14^{\mathrm{a}} \\
(2.856)\end{array}$ & $\begin{array}{l}12.72^{\mathrm{ab}} \\
(2.947)\end{array}$ & $\begin{array}{c}12.16^{b} \\
(3.326)\end{array}$ & 5.37 & $<0.001$ \\
\hline
\end{tabular}

Variables marked with $a{ }^{*}$ differed significantly between experimental conditions. Shared superscript letters indicate that the means did not differ significantly, whilst different superscript letters indicate that the means differed significantly. 
In the case of attitudinal statements, the majority of these also measured statistically significant differences based on which condition group the respondent was in.

Almost universally, the condition where cultured meat was framed as being accepted overseas led to the least positive consumer perceptions on average, followed by the condition where cultured meat was framed as high-tech.

Conversely, the frame describing cultured meat as having health benefits, being a reliable supply of protein, and having an ethical impact were often significantly more well received than the two other frames.

\subsection{Survey: product format and naming}

In regards to the format in which respondents would be willing to buy cultured meat, over $40 \%$ said they would purchase it as a processed meat product (e.g. in a snack sausage or spam), while $29 \%$ would buy it as stuffing meat (e.g. for dumplings or steamed buns), and $28 \%$ would buy it in the format of steak. This was compared with responses to the question, 'what type of meat did you eat in your last three meals?', where respondents were given the same options. Notably, while $40 \%$ of respondents were open to processed cultured meat products, only $23 \%$ had eaten a processed meat product in their last three meals. Conversely, while $49 \%$ had eaten meat on the bone during one of their last three meals, only $19 \%$ elected to purchase cultured meat on the bone. Table 3 on the page following illustrates these results alongside the rates at which respondents had recently consumed those same products in their last three meals.

Participants indicated which types of meat products they had eaten in their last three meals the most common choices were meat on the bone (49.8\%), shredded meat (45.1\%), and sliced meat $(39.8 \%)$. There were considerable differences in participants' willingness to buy cultured meat products of different types: whilst $27.2 \%$ said they would buy cultured sliced meat, just $19.8 \%$ said they would buy meat on the bone. The most popular option for cultured meat was processed meat (e.g. sandwich or sausage meat) - in general, the types of meat which were most preferred for cultured meat were products which were more processed. This may be because these products are already considered somewhat processed or unnatural, or because the texture of these products is considered less important than dried meat, for example.

In choosing which name was most attractive for cultured meat from nine options, $24.9 \%$ of respondents chose peiyangrou (literally: cultivated meat, 培养肉, the name used in the survey instrument itself) while $17 \%$ chose peizhirou (literally: cultured meat, 培植肉). $34 \%$ of respondents believed that peiyangxibaorou (literally: cultivated cell meat, 培养细胞肉) was most accurate, 
followed by $28 \%$ who believed that peiyangrou was. These results are presented in Graph 1 below.

\begin{tabular}{|c|c|c|}
\hline \multicolumn{3}{|c|}{ Table 3: Variance in popularity of different cultured meat (CM) products } \\
\hline Type of meat & \% who would purchase as CM & \% who ate recently (last 3 meals) \\
\hline $\begin{array}{c}\text { Processed meat } \\
\text { e.g. sausages }\end{array}$ & 40.2 & 23 \\
\hline Stuffing meat & 29.3 & 28.5 \\
\hline Steak & 28.4 & 39.4 \\
\hline Slices of meat & 27.2 & 45.1 \\
\hline Shredded meat & 25.3 & 28.7 \\
\hline Minced meat & 24.3 & 29 \\
\hline Diced meat & 20.9 & 3.8 \\
\hline Meat floss & 20.7 & 49.8 \\
\hline Meat on the bone & 19.8 & 3.5 \\
\hline Dried meat & 18.8 & \\
\hline
\end{tabular}

\section{Graph 1}

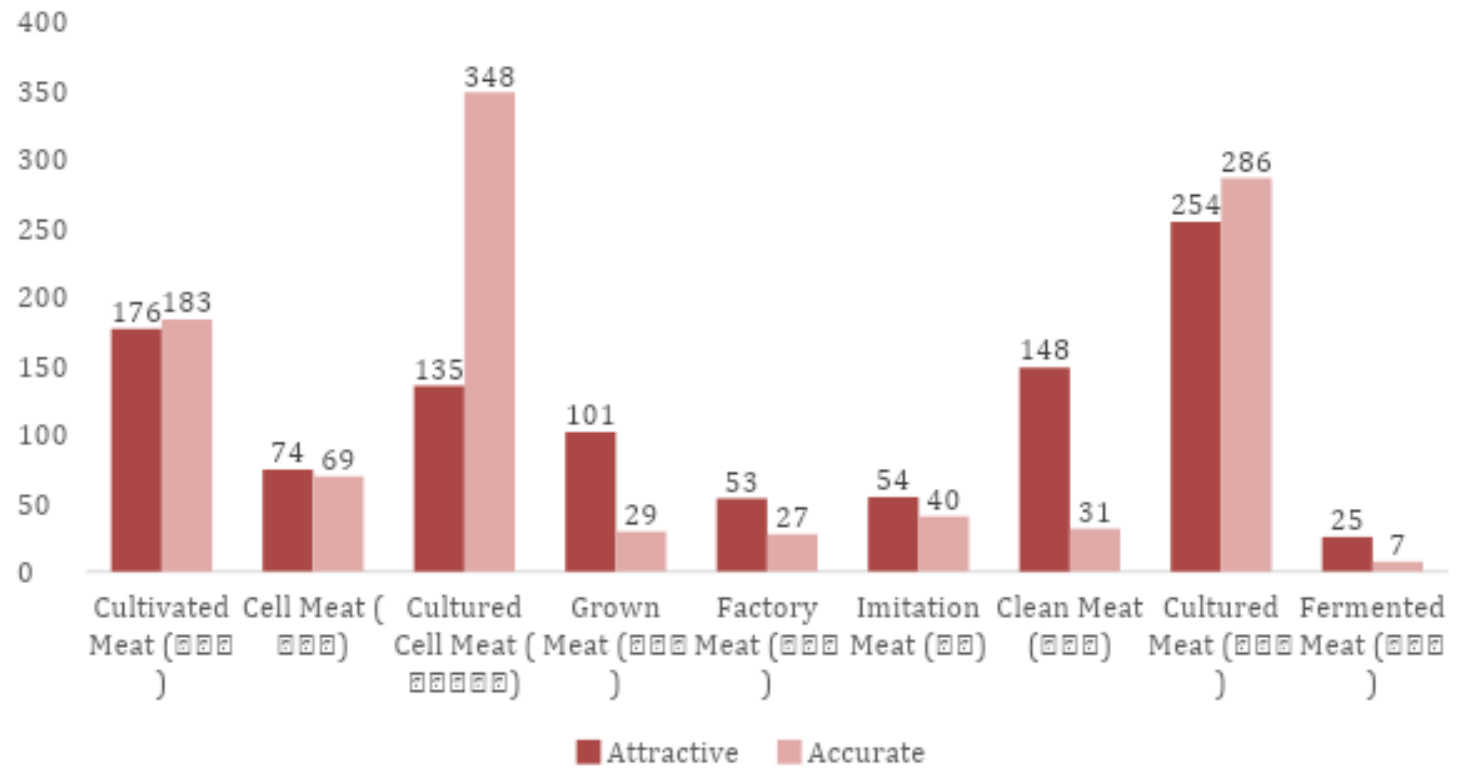




\subsection{Interview: participants}

Interviews were conducted with 17 individuals, all stakeholders in the future of cultured meat in China and subject matter experts from relevant backgrounds. This included three representatives of investment groups focussed on the nexus between future food and China, four representatives of the incumbent meat industry (including international and domestic, private and state-owned companies), four founders of cultured meat start-ups, three experts from think tanks focused on the area, and two academics from the fields of consumer behaviour and agricultural science. Across post-interview analysis of raw data, broad themes were evident, which are outlined below.

\subsection{Interview: themes}

\section{(A) Development of cultured meat in China lags behind the West, but may accelerate quickly given the right conditions}

Despite the fact that there is significant outsider interest in China as a market, and some interest from within China looking at the development of the industry internationally, there is little collaboration and connection across borders. The collaboration that is occurring is largely pushed by private investors who are the quickest to recognise the size and potential of the Chinese market.

Almost all interviewees emphasised the difference in interest in cultured meat between China and the West. While in the US and elsewhere there is a strong emphasis on the ethical and environmental aspects of cultured meat, interviewees emphasised that in China these areas of focus for consumers are still only in emerging stages. For policy makers, however, cultured meat may provide a solution to the future problem of insufficient meat supply to meet increased demand.

One of the current hurdles to the commercialisation of cultured meat globally is government regulation. Aspects such as food standard approval and labelling requirements may be the responsibility of governmental regulatory bodies, but it is also widely acknowledged that meat industry incumbents are contributing to this debate and development too (especially in the USA), usually in an attempt to slow cultured meat's entry to the market (Garfield, 2018). In China, the role of government in the development of cultured meat could be a lot more involved. All the interviewees who commented on this noted that the future of the cultured meat industry in China would be heavily dependent on the attitude of the government.

If the government recognizes the benefits of cultured meat as a strategy to deal with its future protein deficit and environmental issues then there could be strong support for researchers and 
companies working in the area, with an expedited track to market through quickly developed regulation. Alternatively, if the risks of cultured meat to public sentiment and technological issues is weighted more heavily then there may be continual roadblocks to its successful movement to market; from food safety standards, to regulation because of its novelty, to other logistical barriers that will emerge and be hard to overcome without government support. Of those interviewees who discussed this issue, they all noted that for the government the priority for such support would be partially determined by levels of acceptance amongst the general public.

The reception from the general public is important to the government mostly because when a food safety crisis occurs, at some level the government is usually responsible (Wu, Yang and Chen 2017). Therefore, unless it is likely that that reception would be positive and that the technology is safe, it is unlikely that there will be significant development or welcoming of the industry.

Some interviewees, especially those with an investment background, noted that if domestic production of cultured meat were to develop in China, it may undercut Western prices of production. Lower prices for the labour and raw technological materials involved may combine with existing advanced bioreactor technology and infrastructure required to cultivate meat. While this may change over time as the economy develops, it makes China an ideal initial growth location for cultured meat production.

\section{(B) China has an existent relationship with alternative protein}

Plant-based and cultured meat are different products that are often considered under the same heading of 'alternative protein'. While this is understandable in some forums, it causes confusion amongst the general public about two products that are entirely different in terms of their production, composition and nutritional profile. Plant-based meat is made from entirely non-animal products, while cultured meat has the same content as conventional meat, albeit made through a different production process. This confusion and conflation of the two is even more common in China because of the nomenclature associated with the area. Both cultured and plant based meat have been called 'man-made meat' (renzaorou, 人造肉), which not only arouses associations of unnaturalness and past meat scandals, but also makes it hard to differentiate cultured from plantbased meat.

The reason why this is of relevance in China is because of China's long history of vegan meat imitations. Interviewees all reiterated that China's historical relationship with 'plant-based meat' is different from the West, and so plant-based meat cannot be considered an entirely novel, new 
product in the way that cultured meat can. The development of mock meat in China stretches back to at least the Tang Dynasty (618-907), and it has long been a staple of modern cuisine and consumption for specific groups in society, namely vegetarians and vegans, diets often adopted by Buddhists (Dunlop, 2018).

While mock meat is still sometimes consumed by meat eaters and does have some healthy connotations, it comes with loaded meaning and would not be seen as interchangeable with conventional meat, which is what plant-based meat companies largely strive to be considered as. Similarly, the consumption of products considered predominantly 'vegan' in the West, such as tofu, are not considered as such in China e.g. tofu is a common ingredient in many dishes with meat. For this reason, there is some uncertainty as to how Chinese consumers will respond to plant-based meat products. Some international companies such as Beyond Meat and Impossible Foods may act as test cases, alongside domestic start-ups in the area such as Zhen Meat (zhenrou, 真肉). Similarly, cultured meat companies will need to be aware of how to adapt their marketing in China, and keep in mind that Chinese consumers' perceptions may be significantly different from those in the West (Bryant et al., 2019).

\section{(C) The Chinese consumer's increasing embrace of convenience}

Chinese consumers are increasingly embracing meat in a more packaged form, in part due to the food safety boon implied, as well as for convenience reasons (Kuo, 2013). It is still relatively common for meat to be bought in a wet market, slaughtered fresh or bought live in China, but this tradition is slowly dying, largely with the support of a government wishing to be able to better police production and avoid public health crises brought on by unhygienic slaughter and sale of animal meat (DuBois \& Gao, 2017). As Chinese consumers move to embrace supermarket shopping, their purchase of meat will likely also transition to being pre-packaged and disconnected from the concept of an animal.

Chinese consumers are also aligning with global trends in the rising propensity to eat in a snacking manner (rather than purely three meals a day). To facilitate such trends, often encouraged by busy work schedules and the idea that snacking somehow can be considered healthier, there has been a growth in snack foods (Daxue Consulting, 2019). These kinds of products can differ largely but they are often of a multi-processed nature. While not popular in Western countries, a common snack found across China in various forms is processed meat sausage. A strong example of a snack which is marketed as meat, but which has a host of different filler ingredients; sausages like this would be the ideal vessel for cultured meat. 


\section{(D) Chinese choice and use of meat products differs from the West}

Diversity of animals, cuts and meat products in Chinese food is common. This was cited by interviewees as an ongoing issue to consider if and when cultured meat is marketed toward the Chinese, and more broadly Asian, market.

While cuts of meat are often purchased in China, it is very rare to see large cuts of meat at the centre of a Chinese meal. Much of Chinese cooking uses meat as an element of flavour and garnish in a dish as opposed to the central and overwhelming focus e.g. putting mince through a vegetable dish or making dumplings with a mixture of meat and vegetables (Phelps, 2018). This style of cooking uses higher amounts of mince and diced meat. In this way, the format of meat used in Chinese cooking may be more amenable to cultured meat.

Another relevant consideration is the variety of meats and meat products purchased by Chinese consumers. This can be highlighted by Avant Meat's flagship product of fish maw which, uncommon outside of Asia, attracts a high price due its rarity, meaning that Avant may be able to avoid the overwhelming issue of needing to sell their product at a very low cost to be competitive (as is the case with mince).

Consistently mentioned by interviewees was the Chinese consumer tendency to prioritise food safety, as well as price and quality, over more emotive narratives about nature or ethical impact. The quantitative data supports the view that food safety was an important message. One interviewee described Chinese consumers as more 'ruthless', and said that they would prioritise products that offered good quality (for example including added nutritional benefits). This is partly due to the myriad incidences of food safety scandals in recent Chinese history, which continue to define Chinese consumer attitudes towards food products, especially those that are novel. From 'zombie' meat which is defrosted after decades, to 'synthetic' meat which involves combining multiple different meat products but selling it under a different name, the sensational and highly publicised nature of food safety scandals, including in relation to meat (Cong and Min 2013), has ensured that Chinese consumers are more suspicious of the origins of what they eat. It will be important to clearly differentiate cultured meat from these scandals. 


\section{Discussion}

\subsection{Experimental findings}

The highest performing frame in regards to a composite measure of behavioural intentions emphasised the potential health benefits of cultured meat. This characteristic may be unique to the Chinese, or broader Asian, market, especially considering that previous similar research with a US sample indicated that informing respondents that cultured meat could be nutritionally enhanced did not significantly affect their behavioural intentions (Baumann and Bryant 2019). The research undertaken by Baumann and Bryant used a similar experimental survey format and four measures of behavioural intentions as used in the present survey, making it a fairly robust comparison.

In China, the nutritional properties of food are often considered to contribute to a holistic version of health, with many types of food recommended for medicinal reasons connected to Chinese traditional medicine and non-Western conceptions of wellness. As a result, Chinese consumers place considerable importance on the properties of food products, and meat is generally considered to have high nutritional content (Phelps 2018). Additionally, food safety is a known priority for Chinese consumers, something the frame also emphasised as a benefit of cultured meat. Important to note is that while this frame often performed significantly better than other frames, the broader sample still believed that cultured meat was less nutritious than conventional meat, which should doubly emphasize the importance of educating consumers about the health profile of cultured meat products.

The highest performing frame in regards to attitudes and beliefs was that which emphasised the positive ethical impact of cultured meat. This is unsurprising given that this frame directly noted benefits to animal welfare and the environment, which were also two of the beliefs measured. Previous studies on consumer awareness of the impact of animal farming on emissions in China indicate that the general public is largely unaware of the large impact that industrial animal agriculture has on emissions (Wellesley, Happer and Froggatt 2015). As knowledge of the impact of animal farming grows in China, framing that emphasizes the environmental benefits of cultured meat may grow to become more popular.

Attitudes and beliefs are important when considering whether cultured meat may be well received in China, but of greater relevance are likely behavioural intentions. A recent study done on attitudes towards vegan and vegetarian diets in the UK indicate that even though consumers may be aware of the environmental, health and animal welfare benefits of such diets, ultimately it 
is beliefs about the sacrifices to taste, convenience and cost that put consumers off transitioning (Bryant 2019).

This trend of attitudes and beliefs not reflecting behavioural intentions may also be reflected in the relative success of the reliable supply frame in positively influencing attitudes and beliefs, but not so much in regards to behavioural intentions. While a respondent may believe that cultured meat is good for Chinese society as a whole because they recognise the country has an inability to meet meat demand, it may not mean that the respondent themselves would be personally willing to eat, buy and pay more for cultured meat. This divergence between recognizing benefits of cultured meat for society but being wary of consuming it as an individual has been noted in previous research (Verbeke et al. 2015). Again, this underlines the importance of highlighting personal benefits to the consumer.

When the various frames were originally conceived, all but the high-tech development frame were considered, after qualitative interviews and independent research, to be credibly attractive to Chinese consumers. In one interview, an investor (who was not Chinese) posited that what may succeed in the Chinese market would be branding which associated cultured meat with a Western consumer culture; and that once the product was accepted and deemed safe in other jurisdictions, Chinese consumers would be eager to purchase. This aligns with trends when it comes to other sensitive food products such as milk formula and even conventional meat, both the subject of domestic scandal and then subsequent increased import demand (Kendall, et al., 2018). While it may therefore seem surprising that this frame performed so poorly, it may be explained by recent rises in trust of Chinese brands generally and growing preference for them amongst Chinese consumers (McKinsey 2019). Certainly, framing cultured meat primarily as a Non-Chinese product is unlikely to be as appealing to consumers as other frames.

\subsection{Comparison with original experimental survey on framing}

Broadly speaking, significance in the difference between responses of participants to cultured meat based on the frame they were exposed to was more exaggerated in the original experimental study than here (Bryant and Dillard 2019). This may be explained by research that demonstrates that Asian survey respondents are less likely to have 'extreme response styles' that are more common amongst Western survey respondents (Peterson, Rhi-Perez and Albaum 2014). As such, it would be likely a survey instrument administered in China would deliver responses that are considerably less polarised than the same instrument administered in the USA. 


\subsection{Comparison with prior findings on Chinese consumer acceptance}

The overall data partially confirms previous findings of the prior US-India-China survey that Chinese consumers are quite positive about cultured meat, reflected in their high willingness to try, purchase and substitute cultured meat for conventional meat.

Unfortunately, the imbalance caused by the use of differently weighted Likert scales makes the two groups of data not directly comparable. Despite this, it is notable that the proportion of respondents who responded negatively to behavioural intention statements on cultured meat remained the same between both survey samples. As such, the data collected for this study can be said to confirm the positive results of that survey in the sense that only a small proportion of the Chinese population are categorically not accepting of cultured meat. This is despite this study addressing the potential sources of bias in that study by using a more evenly balanced response mechanism and neutral name for cultured meat, as well as surveying a broader demographic.

The findings also confirm prior research that consumers are more likely to positively rate the extrinsic factors of cultured meat (such as environmental, welfare and social benefits) over intrinsic factors (such as safety, health, naturalness). It is important to recognise that while the former may indicate broad public support for cultured meat, ultimately it is more likely to be

intrinsic factors that actually motivate consumers to purchase cultured meat (Mancini and Antonioli 2019). Ultimately it is these consumer decisions that will determine whether cultured meat will actually be adopted and have the intended impact.

\subsection{Product format and naming}

Results indicate that Chinese consumers may be more open to processed meat products that are not commonplace in Western markets but which are popular in China, and Asia more broadly. Such products, such as processed meat products including sausages and luncheon meat, are frequently sold as snacks at small shops and street vendors, as well as in convenience stores and demand for these products is growing (Peverelli, 2019).

Naming cultured meat is an ongoing issue for the cultured meat industry, which seeks to balance transparency yet attractiveness to consumers, without offending the incumbent conventional meat industry, which may be key to bringing the product to market (Szejda and Urbanovich 2019). While the debate on naming has not fully actuated in the Mandarin language, it will no doubt be an issue as cultured meat and plant-based meat companies wish to differentiate themselves, a feat that is hard in the current circumstances, where both products are colloquially 
called renzaorou (literally: man-made meat, 人造肉). Considering that the use of different names for cultured meat produces significantly different levels of consumer acceptance (Bryant and Barnett 2019), it is important to understand which names will have the most positive impact while also being acceptable to regulators and incumbent industry. In this context, the names favoured by respondents in the survey provide a good initial focal indication and some names can now be avoided, such as gongchangrou (literally: factory meat, 工厂肉, which fewer than $3 \%$ of respondents believed was an accurate name), which has been said to be used by some government officials; and fajiaorou (literally: fermented meat, 发酵肉, which fewer than 3\% of respondents believed was an attractive name), which was suggested by some scientists in the area. Because the predominantly popular name chosen by survey respondents was that which was used throughout the survey when referring to cultured meat, there could be further research undertaken to examine whether this name is genuinely attractive and accurate, or whether it was considered so because of its predominant use.

\subsection{Suggestions for industry}

\section{Adjust to the Chinese, and Asian, market}

While there may be differences in markets for cultured meat between the United States and Europe, China's historical and cultural relationship with meat means the Chinese consumption of cultured meat may look significantly different to that in the other parts of the world, where the majority of research on consumer responses has been done. China may be the world's future largest protein market, but other countries, including some neighbours of China, will also become some of the biggest meat consumers in decades to come. Not all these countries share the same attitudes towards, and historical cultures of, meat consumption (e.g. India), but others, especially those with strong Chinese diaspora populations or historical connections, including the majority of East and Southeast Asia, may reflect similar attitudes to those found in this study (see YouGov, 2018). This may be useful for industry so that it is able to expand its footprint in the region without needing to have decisively different strategies for each market. Past research in some key countries have extrapolated their findings to a broader cultural diet that they may be relevant to, such as research on Italian consumer responses to cultured meat (Mancini and Antonioli 2019), which was connected to the Mediterranean diet more broadly. 


\section{Tailor messaging and increase outreach}

Industry and policy makers encouraging adoption of cultured meat should be mindful of the impact of framing on consumer acceptance, as evidenced by this study. When sharing information about cultured meat, stakeholders may take into account the varying success of different frames on positively impacting behavioural intentions, attitudes and beliefs. Broadly speaking, messaging that incorporates the food safety and other potential health benefits of cultured meat is likely to be most advantageous in garnering acceptance of cultured meat. This aligns with both the quantitative data and stakeholder insight on the importance of food safety and nutrition to the Chinese consumer.

Chinese consumers who stated that they knew what cultured meat was were significantly more likely to try, buy and substitute conventional meat. While prior research found that only $34 \%$ of consumers were not familiar with cultured meat (Bryant, Szejda, et al. 2019), this survey found that almost $60 \%$ of respondents had not heard of cultured meat. We also observed greater acceptance of cultured meat was also the same for those consumers who wished to know more about cultured meat (85\% of the survey population). In regards to other agri-food technologies, such as genetically modified foods, research has made clear that once established, negative perceptions are hard to reverse (Frewer 2017). For this reason, industry and stakeholders should seek to start sharing information about cultured meat as soon as possible, albeit in a considered manner, instead of waiting to engage with consumers until a definitive product offering and entry date are clear. Instead,

In recent research on Chinese consumers, traceability of food products is shown to be conducive to greater profitability, also an indication of how transparency can improve consumer adoption (Bai and Zhu 2019). More broadly, transparency has been identified as the underpinning of gaining trust, key to establishing effective science communication, including in the area of cultured meat (Szejda and Urbanovich 2019). The extent to which stakeholders may share information about cultured meat could be an area of further exploration; indeed, conducting a similar experimental survey where each group is exposed to a differing amount of information about cultured meat may be conducive to a better understanding of how best to satisfy the consumer's demand for more information.

\section{Tailor product development}

Considering that the product most respondents said they would purchase cultured meat as (that is, processed meat products) is not really the focus of any current start-ups in the area, industry would be well advised to consider how they may tailor their products to the Chinese 
market. Processed meat products which are popular in China, such as snack sausages and other small snacks that are individually packaged and aimed at convenience, may be ideal. These are products that would be developed with the Chinese, and broader Asian, market in mind, and so businesses should work from a base of comparison with current products in the Asian market. The flavour profile, style of packaging and ingredients should be tailored to a Chinese palate. This may create opportunities for collaboration with the same companies that currently dominate the market for meat in China, but industry should at least be aware that what may be an ideal format for introducing cultured meat in a Western market may not be ideal in China.

The tailoring of the product extends also to the type of animal meat itself. While a meat shelf in an American supermarket may have four common animal meats (cow, pig, chicken and fish), in perhaps up to five different cuts, Chinese supermarkets broadly maintain the diversity of the traditional wet market in so far as they may offer more types of meat, as well as in more formats. This especially applies to seafood, an area where Asian tastes are considerably broader than in the West. An applied example of this is in Avant Meats, which launched with the development of cultured fish maw: a meat product that is relatively expensive and for which there is significant demand in China, but would not be considered as saleable in a Western context.

For companies that are considering more diverse types of animal meat for cultivation, it is likely that such novelty may be better received in China than in Western countries. Previous research in a Western context found that consumers were unlikely to try atypical animal meats when cultured (Wilks \& Phillips, 2017), though this not has been explored in great depth. While studies in a Western context have identified food neophobia as the best indicator of rejection of cultured meat, it is worth noting that food neophobia levels in China are lower (Bryant, Szejda, et al. 2019), which not only aligns with the greater levels of acceptance of cultured meat confirmed, but also may indicate that Chinese consumers are open to more diverse products (Wilks, Phillips and Fielding, et al. 2019). Given that China's consumption of wild and rare animals may be threatened by government legislation in the wake of COVID-19, demand for such unique animal meats in a cultured form may also be a growth area.

\section{Tailor entry strategies}

Companies must be cognisant of the complex business and, more relevantly, regulatory environment which they encounter in China. Regulation of cultured meat across the world is a pain point for companies in the area, and China may not be an exception. Aside from this, doing business in China more broadly also invites further complexities than in other more open markets: considerations such as intellectual property, the competitive environment given the makeup of 
private and publicly owned companies, as well as the sheer size of the country are all major considerations that should be central to any entry and ongoing strategy development.

In the USA, major agricultural giants Tyson Foods and Cargill (the second largest processor of chicken, beef and pork, and the largest privately held company in the USA, respectively), have been significant investors in cultured meat companies both domestically and abroad (Piper 2019). Chinese companies such as WH Group (the largest pig meat producer in the world, which also owns Smithfield), New Hope Group (the largest producer of animal feed in China, with subsidiaries across 30 countries internationally), and COFCO (China's largest food company) will be important to consider as stakeholders in the development of a cultured meat market in China, either as incumbent actors that will face disruption or as potential investors. These companies, and many others like them, are key to providing for China's protein needs and, similar to their counterparts overseas, are well established amongst supply chain and logistics networks that are essential to reach Chinese consumers. 


\section{Future research areas}

\section{Further exploration of regional attitudes towards cultured meat}

As the world's future largest protein market, it is important to recognise the diversity of the Chinese consumer market. Relevant to cultured meat companies, meat consumption in China differs broadly depending on region. While Xinjiang and other provinces with high Muslim populations consume minimal levels of pork compared with the national average (Ma, Huang, Rozelle, \& Rae, 2003), there are also significant variations in consumption levels and trends between different tiers of cities and urban/rural divides (Mao, et al. 2016).

Foreign companies are often focused on affluent consumers in traditional Tier-1 cities like Beijing or Shanghai, but should also consider Tier-2 and Tier-3 cities who are more likely to experience increased levels of meat consumption as incomes rise (Perrett 2018) ${ }^{1}$. In recent years, the number of middle-class consumers in Tier-3 and Tier-4 cities has increased at a rate approaching double that of Tier-1 and Tier-2 cities (McKinsey 2019). As such, further exploring more specific consumer segments' attitude to, and acceptance of, cultured meat across China's diverse population would provide insight into which parts of Chinese society may be most receptive to, and earlier adopt, cultured meat.

\section{Further exploration of how China's tastes may affect cultured meat product development}

Considering China's large market for either rare or endangered animal meats and products (not only for cuisine, but also for medicinal purposes), it may be interesting to further explore the potential for such products in a cultured meat format for the Chinese market. Different types of meat pose different challenges to cultured meat scientists and being able to develop products in a wider variety of formats and from different animals may be a boon to development of the industry, if it means there is plenty of opportunity for product differentiation.

\footnotetext{
${ }^{1}$ Considering the demographic diversity across China, commercial actors, commentators and the general public will often refer to Chinese cities through reference to 'tiers'. The tiering system generally refers to a ranking dependent on the wealth and population of a city. The tiering system has also been said to include its political position (South China Morning Post, 2016). Traditional Tier 1 cities were limited to Beijing, Shanghai, Guangzhou and Shenzhen but as China develops so too do the number of cities in each tier.
} 


\section{Conclusion}

By 2025, China will be the world's largest market for protein, valued at over USD $\$ 138$ billion (Food Innovation Australia Limited 2019). As China's meat consumption continues to increase, it is important to answer the question of where this meat can be sourced from and what impact its production will have on humanity and the planet. If this meat is sourced from conventional industrialised animal farms then this rise in consumption will be accompanied by corresponding increases in threats to human health, not only at a Chinese domestic level, but globally. From growth in zoonotic contagious diseases to antimicrobial resistance caused by consumption of antibiotics in farmed meat, these threats should be identified by stakeholders who are considering the future of China's meat production and imports, before they become overwhelming issues of concern for the general public.

Threats aside, the instability of farm animal populations due to disease (such as African Swine Fever), climate events (such as forest fires in Australia) and a volatile global supply chain (evidenced by the COVID-19 pandemic), make industrially farmed meat an unreliable meat source. Considering the importance of ensuring protein for China's future generations, cultured meat may be a solution which avoids the aforementioned problems. This situation raises a potential debate, similar to that which has arisen in regards to the environmental footprint of a rising China (in a world threatened by climate change, wrought by carbon emissions from Western countries); if the Global North was able to enjoy conventionally farmed animal meat for so long, why should that now be denied to the Global South? Rather than considering such scenarios as a zero-sum game, China may consider the current situation as an opportunity to further develop a reputation for innovation, and in regards to a problem of global significance. This will not only have corresponding gains on the global stage of international relations and powerbroking, a stage China increasingly seeks to influence (Hilton 2018), but also can provide a showcase of ethical and sustainable development for the Global South countries that China has now become a model for.

While intensive animal farming is not yet common in sub-Saharan Africa and countries like Pakistan, these regions will also experience elevated growth in demand for meat products in years to come. China may create the standard by which these countries can learn to develop their own meat industries, and on the contrary to the debate mentioned above, actually develop food sovereignty for their citizens, similar to the manner in which Singapore is pioneering the space (Neo, 2020).

Although cultured meat may have long-term benefits for public health and the environment, it will ultimately need to succeed as a commercial product that requires consumer 
adoption. Stakeholders may be able to encourage that adoption through public awareness campaigns and advertising, but this must be done with a mind to the preferences and interests of consumers themselves. As such, understanding how to frame descriptions of cultured meat and develop products that are attractive to Chinese consumers is of vital importance 


\section{Acknowledgements}

I would like to thank my advisor, Professor Lin Wanchuan, for all her assistance throughout the thesis process. I would also like to thank all of the interviewees for this study, and hope that my research may be of interest and value to them.

The Cellular Agriculture Society is grateful to the Tipping Point Private Foundation for funding our work in social science. 


\section{References}

Bai, Jun-fei, and Chen Zhu. 2019. "Food economics and policies: Challenges and approaches toward better nutrition and safer food in China." Journal of Integrative Agriculture 1737-1739.

Baumann, Fabian, and Chris Bryant. 2019. "Can Nutritional Enhancements Boost The Consumer Appeal of Cultured Meat?" Open Science Framework September.

BBC. (2010, July 09). China dairy products found tainted with melamine. Available at https://www.bbc.com/news/10565838

Browning, C. J., Qiu, Z., Yang, H., Zhang, T., \& Thomas, S. A. (2019). Food, Eating, and Happy Aging: The Perceptions of Older Chinese People. Frontiers Public Health, online.

Bryant, Christopher J. 2019. "We Can't Keep Meating Like This: Attitudes towards Vegetarian and Vegan Diets in the United Kingdom." Sustainability online.

Bryant, Christopher J, and Julie C. Barnett. 2019. "What's in a name? Consumer perceptions of in vitro meat under different names." Appetite 104-113.

Bryant, Christopher, and Courtney Dillard. 2019. "The Impact of Framing on Acceptance of Cultured Meat." Frontiers in Nutrition online.

Bryant, Christopher, Keri Szejda, Varun Deshpande, Nishant Parekh, and Brian Tse. 2019. "A Survey of Consumer Perceptions of Plant-Based and Clean Meat in the USA, India, and China." Frontiers in Sustainable Food Systems.

Bryant, Christopher, and Julie Barnett. 2018. "Consumer acceptance of cultured meat: A systematic review." Meat Science 8-17.

Cellular Agriculture Society. 2019. Fellowship Series. 27 October. https://www.cellag.org.

陈碧云. 2019. 第一届全国植物蛋白肉和细胞培养肉制造技术高峰论坛 (第一轮通知). 23 September. http://news.jiangnan.edu.cn/info/1132/61607.htm.

China Plant Based Foods Association. (2019). CPBFA: the development of alternative proteins complements the conventional meat industry. Retrieved from China Plant Based Foods Association: http://www.pbfa.org.cn/futurefood2019

Choi, C. (2018, June 19). Meat 2.0? Clean meat? Spat shows the power of food wording. Retrieved from Associated Press: https://apnews.com/d61aa520e6204b85b5dae69e925db8a9

Choudhury, D., Tseng, T. W., \& Swartz, E. (2020). The Business of Cultured Meat. Science \& Society, 573-577.

Chow, Yau Shun. 2018. China is Ready for an Animal Welfare Movement. 14 November. https://www.sixthtone.com/news/1003191/china-is-ready-for-an-animal-welfare-movement.

Cong, Dai, and Jiang Min. 2013. "Fake meat scandals add to Chinese food fears." BMJ 346.

CNBC. (2015, July 12). China watchdogs to track down smuggled 'zombie meat'. Retrieved from CNBC: No substitute for taste: how the clean meat industry is finding its flavours

Daly, Jon, and Bill Birtles. 2019. China struggles to contain African swine fever, resorts to mass live-pig burials, millions of culls. 30 May. https://www.abc.net.au/news/rural/rural-news/201905-30/mass-live-pig-burials-millions-culled-china-african-swine-fever/11146642.

Daxue Consulting. (2019, February 18). What international brands must know about the domestically dominated healthy snacks market in China. Retrieved from Daxue Consulting: https://daxueconsulting.com/healthy-snacks-market-in-china-daxue-consulting/

DuBois, T. D., \& Gao, A. (2017). Big Meat: The rise and impact of mega-farming in China's beef, sheep and dairy industries. The Asia-Pacific Journal, online.

Dunlop, F. (2018, August/September). China, the birthplace of fake meat. The Economist. Retrieved from The Economist: https://www.1843magazine.com/food-drink/china-thebirthplace-of-fake-meat 
Ellis, Linden. 2007. Environmental Health and China's Concentrated Animal Feeding Operations (CAFOs). Research Brief, China Environment Forum.

Food Innovation Australia Limited. 2019. Protein Market: Size of the prize analysis for Australia. Canberra: Food Innovation Australia Limited.

Frewer, L. J. (2017). Consumer acceptance and rejection of emerging agrifood technologies and their applications. European Review of Agricultural Economics, 44(4), 683-704.

Garfield, L. (2018, June 10). There's a growing battle between fake meat startups and Big Beef, and neither side is backing down. Retrieved from Business Insider:

https://www.businessinsider.com/beef-companies-file-petition-against-lab-grown-meatstartups-2018-2? $r=U S \& I R=T$

Hancock, T. (2019, September 3). China acts on 'major political task' of high pork prices. Retrieved from The Financial Times: https://www.ft.com/content/4f846fba-ce07-11e9-99a4$\underline{b 5 d e d 7 a 7 f e 3 f}$

Hejazi, Mina, Jue Zhu, Mary A. Marchant, and Xing Ning. 2017. "China's Meat Import Demand: The Impact of Supplier Diversification on U.S. Exports." International Agricultural Trade Research Consortium's (IATRC's) 2017 Annual Meeting: Globalization Adrift. Washington: International Agricultural Trade Research Consortium, 3 December.

Hilton, Isabel. 2018. When China rules the world. 14 May. Accessed April 10, 2020. https://www.prospectmagazine.co.uk/magazine/when-china-rules-the-world.

Hocquette, Aurélie, Carla Lambert, Clémentine Sinquin, Laure Peterolff, Zoé Wagner, Sarah P F Bonny, André Lebert, and Jean-François Hocquette. 2015. "Educated consumers don't believe artificial meat is the solution to the problems with the meat industry." Journal of Integrative Agriculture 273-284.

Huang, Y. (2020, January 1). Opinion: Why Did One-Quarter of the World's Pigs Die in a Year? Retrieved from The New York Times: https://www.nytimes.com/2020/01/01/opinion/chinaswine-fever.html

Israeli Ministry of Finance. (2017, November 9). Finance Minister Kahlon Signs $\$ 300$ Million Agreement with Chinese Counterpart in Beijing. Retrieved from Ministry of Finance: https://mof.gov.il/en/PublicationsAndReviews/PressReleases/Pages/Press_11092017.aspx

Kaiman, J. (2013, May 3). China fake meat scandal: telling your rat from your mutton. Retrieved from The Guardian: https://www.theguardian.com/world/2013/may/03/china-fake-meat-ratmutton

Kendall, H., Naughton, P., Kuznesof, S., Raley, M., Dean, M., Clark, B., . . Frewer, L. J. (2018). Food fraud and the perceived integrity of European food imports into China. PLOS ONE, online.

Kevany, S. (2019, September 12). No substitute for taste: how the clean meat industry is finding its flavours. Retrieved from The Irish Times: https://www.irishtimes.com/news/science/nosubstitute-for-taste-how-the-clean-meat-industry-is-finding-its-flavours-1.4002651

Kuo, L. (2013, September 23). By 2015, China will be the world's largest consumer of processed food. Retrieved from Quartz: https://qz.com/127235/by-2015-china-will-be-the-worlds-largestconsumer-of-processed-food/

Lusk, Jayson L., Jutta Roosen, and Andrea Bieberstein. 2014. "Consumer Acceptance of New Food Technologies: Causes and Roots of Controversies." The Annual Review of Resource Economics 381-405.

Ma, H., Huang, J., Rozelle, S., \& Rae, A. N. (2003). Livestock Product Consumption Patterns in Urban and Rural China. Massey University.

McKinsey. 2019. China consumer report 2020: The many faces of the Chinese consumer. Consumer report, McKinsey and Company. 
Malhotra, N. K. (2006). Questionnaire design and scale development. In The handbook of marketing research: Uses, misuses, and future advances, SAGE Publications: Thousand Oaks, California.

Mao, Yanwei, Yimin Zhang, David L Hopkins, and Luo Xin. 2016. "Consumption Patterns and Consumer Attitudes to Beef and Sheep Meat in China." American Journal of Food and Nutrition 30-39.

Mancini, M. C., \& Antonioli, F. (2019). Exploring consumers' attitude towards cultured meat in Italy. Meat science, 150, 101-110.

Michaut, Anne M. K. 2004. Consumer response to innovative prod ucts with application to foods. Wageningen: Wageningen University.

Neo, P. (2020, January 22). Next-gen products: Safety first as Singapore delves into regulatory framework for cell-based meat. Retrieved from Food Navigator Asia: https://www.foodnavigator-asia.com/Article/2020/01/22/Next-gen-products-Safety-first-asSingapore-delves-into-regulatory-framework-for-cell-based-meat

Oliveira, Gustavo de L. T. 2017. "Chinese land grabs in Brazil? Sinophobia and foreign investments in Brazilian soybean agribusiness." Globalizations online.

Perrett, Michelle. 2018. China animal protein growth predicted to slow. 31 August. Accessed April 11, 2020. https://www.globalmeatnews.com/Article/2018/08/31/China-meat-consumption-toslow.

Peterson, Robert A., Pablo Rhi-Perez, and Gerald Albaum. 2014. "A cross-national comparison of extreme response style measures." International Journal of Market Research 89-110.

Peverelli, P. (2019, July 3). Muscling in on China's market for meat snacks. Retrieved from Just Food: https://www.just-food.com/analysis/muscling-in-on-chinas-market-for-meatsnacks_id141763.aspx

Phelps, T. (2018). Protein: A Chinese Perspective. The New Zealand Institute for Plant \& Food Research Limited.

Piper, Kelsey. 2019. In India and China, consumers are eager for lab-grown meat. In the US? Not as much. 5 March. https://www.vox.com/future-perfect/2019/3/5/18250033/vegan-vegetarianclean-meat-cultured-plant-based.

Post, M. (2012). Cultured meat from stem cells: Challenges and prospects. Meat Science, 297-301.

Quan, Liu, Lili Cao, and Xing-Quan Zhu. 2014. "Major emerging and re-emerging zoonoses in China: a matter of global health and socioeconomic development for 1.3 billion." International Journal of Infectious Diseases 65-72.

Reuters. (2020, April 17). Still reeling from pig disease, China pork output drops for 6th quarter. Available at https://www.reuters.com/article/us-china-economy-output-pork/still-reeling-frompig-disease-china-pork-output-drops-for-6th-quarter-idUSKBN21Z0CK

Review on Antimicrobial Resistance. 2015. Antimicrobials in Agriculture and the Environment: Reducing Unnecessary Use and Waste. Review paper, Review on Antimicrobial Resistance.

Rolland, N. C., Markus, C. R., \& Post, M. J. (2020). The effect of information content on acceptance of cultured meat in a tasting context. PLOS ONE, Online.

Rossi, Marcello. 2018. The Chinese Are Eating More Meat Than Ever Before and the Planet Can't Keep Up. 31 July. Accessed April 11, 2020.

https://www.motherjones.com/environment/2018/07/the-chinese-are-eating-more-meat-thanever-before-and-the-planet-cant-keep-up/.

Samuel, S. (2020, April 22). The meat we eat is a pandemic risk, too. Retrieved from Vox: https://www.vox.com/future-perfect/2020/4/22/21228158/coronavirus-pandemic-risk-factoryfarming-meat

Schneider, Mindi, and Shelafi Sharma. 2014. China's Pork Miracle? Agribusiness and Development in China's Pork Industry. Technical Report, Institute for Agriculture and Trade Policy. 
Shemie, D., \& Vigerstol, K. (2016, April 29). China has a water crisis - how can it be solved? Retrieved from World Economic Forum: https://www.weforum.org/agenda/2016/04/china-hasa-water-crisis-how-can-it-be-solved/

Siegrist, Michael, Bernadette Sütterlin, and Christina Hartmann. 2018. "Perceived naturalness and evoked disgust influence acceptance of cultured meat." Meat Science 213-219.

Sinclair, M., Zhang, Y., Descovich, K., \& Phillips, C. J. (2020). Farm Animal Welfare Science in China-A Bibliometric Review of Chinese Literature. Animals, Online.

Siu, Elaine, and Graham Miao. 2019. China Plant-based Meat Industry Report 2018. Singapore: Good Food Institute.

Slade, Peter. 2018. "If you build it, will they eat it? Consumer preferences for plant-based and cultured meat burgers." Appetite 428-437.

South China Morning Post. (2016). Urban legend: China's tiered city system explained. Retrieved from South China Morning Post: https://multimedia.scmp.com/2016/cities/

South China Morning Post. (n.d.). The yin and yang of a meat-free regimen. Retrieved from South China Morning Post: https://www.scmp.com/article/997303/yin-and-yang-meat-free-regimen

Sun, Zhic-hang, Qun-li Yu, and Lin Han. 2015. "The environmental prospects of cultured meat in China." Journal of Integrative Agriculture 234-240.

Szejda, Keri, and Tessa Urbanovich. 2019. Meat cultivation: Embracing the science of nature. Project Report, Washington, DC: The Good Food Institute.

The Good Food Institute. (2017). Clean Meat: The Naming of Tissue Engineered Meat. Retrieved from The Good Food Institute: https://www.gfi.org/the-naming-of-clean-meat

Tian, Q., Hilton, D., \& Becker, M. (2018). Confronting the meat paradox in different cultural contexts: Reactions among Chinese and French participants. Appetite, 187-194.

Verbeke, Wim, Afrodita Marcu, Pieter Rutsaert, Rui Gaspar, Beate Seibt, Dave Fletcher, and Julie Barnett. 2015. 'Would you eat cultured meat?': Consumers' reactions and attitude formation in Belgium, Portugal and the UK." Meat Science 49-58.

Watt, Jonathan. 2010. Chinese farms cause more pollution than factories, says official survey. 9 February. https://www.theguardian.com/environment/2010/feb/09/china-farms-pollution.

Wellesley, Laura, Catherine Happer, and Antony Froggatt. 2015. Changing Climate, Changing Diets: Pathways to Lower Meat Consumption. Chatham House .

Wilks, M., \& Phillips, C. J. (2017). Attitudes to in vitro meat: A survey of potential consumers in the United States. PLOS ONE, online.

Wilks, Matti, Clive J. C. Phillips, Kelly Fielding, and Matthew J. Hornesy. 2019. "Testing potential psychological predictors of attitudes towards cultured T meat." Appetite 137-145.

Wu, Xiaolong, Dali L. Yang, and Lijun Chen. 2017. "The Politics of Quality-of-Life Issues: Food Safety and Political Trust in China." Journal of Contemporary China online.

YouGov. 2018. No demand for fake meat. 22 February. https://china.yougov.com/en$\mathrm{cn} /$ news/2018/02/22/no-demand-for-fake-meat/.

Yu, J., \& Wu, J. (2018). The Sustainability of Agricultural Development in China: The AgricultureEnvironment Nexus. Sustainability, online.

Zhang, G., Zhao, X., Li, X., Du, G., Zhou, J., \& Chen, J. (2020). Challenges and possibilities for biomanufacturing cultured meat. Trends in Food Science \& Technology, 443-450.

Zhou, D., \& Dieter, K. (2019). Price transmission in hog and feed markets of China. Journal of Integrative Agriculture, 1122-1129. 